\title{
First report of barley yellow dwarf virus in maize in Tunisia
}

\author{
Imen Hamdi ${ }^{1} \cdot$ Asma Najar $^{1}$ (D) $\cdot$ Hajer Ben Ghanem ${ }^{2} \cdot$ Arvind Varsani $^{3} \cdot$ Ahmed Jemmali $^{1}$
}

Received: 6 June 2019 / Accepted: 10 July 2019 / Published online: 18 July 2019

(C) Società Italiana di Patologia Vegetale (S.I.Pa.V.) 2019

Keywords BYDV-PAV $\cdot$ Maize $\cdot$ Serological test $\cdot$ Molecular test

Barley yellow dwarf virus (BYDV) was identified on barley in Tunisia by Najar et al. (2017). No data is currently available on whether this virus is present on maize (Zea mays).

A field survey was conducted during spring of 2018 in the northeastern region (El Alia) of Tunisia. A total of 140 samples were randomly collected from five maize fields and tested by tissue-blot immunoassay using antiserum against BYDV (Makkouk and Kumari 1996). Fifty-two maize samples (37\%) were positive for BYDV. In parallel, 38 out of $52(73 \%)$ maize samples tested by DAS-ELISA using a polyclonal antibody raised against BYDV-PAV (Bioreba) were positive, suggesting a prevalence of BYDV-PAV in maize in Tunisia.

The occurrence of BYDV was confirmed by RT-PCR using total RNA (Foissac et al. 2005) and the specific BYDV-PAV primer pair BYDV-F (5'-GTTCTGCCTCAACATCGGAT-3') and BYDV-R (5'-GTTCTGCCTCAACATCGGAT-3') to amplify a $740 \mathrm{bp}$ fragment of the coat protein gene (Ratsgou et al. 2005). An amplicon of the expected size was obtained for all the ELISA-positive samples. Then, four amplicons were randomly selected and used for Sanger sequencing. The four BYDV-PAV sequences (GenBank accession numbers MK224487-MK224489 and MK224491) share >96\% identity amongst them and with sequences of BYDV-PAV isolates

Asma Najar

asmanajara@yahoo.fr

1 Laboratoire de Protection des Végétaux, Institut National de la Recherche Agronomique de Tunisie, 1004 El Menzah, Tunisie

2 Laboratoire de Grandes Cultures, Institut National de la Recherche Agronomique de Tunisie, 1004 El Menzah, Tunisie

3 The Biodesign Center for Fundamental and Applied Microbiomics, Center for Evolution and Medicine, School of Life Sciences, Arizona State University, Tempe, AZ 85287-5001, USA from barley in Tunisia (KJ467220-23 and KJ410741) and Iowa, USA (KY593457), and from wheat in Kansas, USA (KU170668). To the best of our knowledge, this is the first report of BYDV-PAV on maize in Tunisia.

\section{References}

Foissac X, Svanella-Dumas L, Gentit P, Dulucq MJ, Marais A, Candresse $T$ (2005) Polyvalent degenerate oligonucleotides reverse transcription-polymerase chain reaction: a polyvalent detection and characterization tool for Trichoviruses, Capilloviruses, and Foveaviruses. Phytopathology 95:617-625

Makkouk KM, Kumari SG (1996) Detection of ten viruses by the issueblot immunoassays (TBIA). Arab J Plant Protect 14:3-9

Najar A, Hamdi I, Varsani A (2017) Barley yellow dwarf virus in barley crops in Tunisia: Prevalence and molecular characterization. Phytopathol Mediterr 56:111-118

Ratsgou M, Khatabi B, Kvarnheden A, Izadpanah K (2005) Relationships of barley yellow dwarf virus-PAV and cereal yellow dwarf virus-RPV from Iran with viruses of the family Lutoviridae. Eur J Plant Pathol 113:321-326

Publisher's note Springer Nature remains neutral with regard to jurisdictional claims in published maps and institutional affiliations. 